M. Regad, M. Helaimi, R. Taleb, H. Gabbar, A. Othman

\title{
OPTIMAL FREQUENCY CONTROL IN MICROGRID SYSTEM USING FRACTIONAL ORDER PID CONTROLLER USING KRILL HERD ALGORITHM
}

\begin{abstract}
This paper investigates the use of fractional order Proportional, Integral and Derivative (FOPID) controllers for the frequency and power regulation in a microgrid power system. The proposed microgrid system composes of renewable energy resources such as solar and wind generators, diesel engine generators as a secondary source to support the principle generators, and along with different energy storage devices like fuel cell, battery and flywheel. Due to the intermittent nature of integrated renewable energy like wind turbine and photovoltaic generators, which depend on the weather conditions and climate change this affects the microgrid stability by considered fluctuation in frequency and power deviations which can be improved using the selected controller. The fractional-order controller has five parameters in comparison with the classical PID controller, and that makes it more flexible and robust against the microgrid perturbation. The Fractional Order PID controller parameters are optimized using a new optimization technique called Krill Herd which selected as a suitable optimization method in comparison with other techniques like Particle Swarm Optimization. The results show better performance of this system using the fractional order PID controller-based Krill Herd algorithm by eliminates the fluctuations in frequency and power deviation in comparison with the classical PID controller. The obtained results are compared with the fractional order PID controller optimized using Particle Swarm Optimization. The proposed system is simulated under nominal conditions and using the disconnecting of storage devices like battery and Flywheel system in order to test the robustness of the proposed methods and the obtained results are compared. References 18, figures 8.
\end{abstract}

Key words: microgrid, frequency control, FOPID controller, Krill Herd, particle swarm optimization.

Анотація. У статті досліджено використання регуляторів пропорційного, інтегрального та похідного дробового порядку (FОРID) для регулювання частоти та потужності в електромережі. Запропонована мікромережева система складається з поновлюваних джерел енергї, таких як сонячні та вітрогенератори, дизельних генераторів як вторинного джерела для підтримки основних генераторів, а також з різних пристроӥв для накопичування енергї̈, таких як паливна батарея, акумулятор $і$ маховик. Через переривчасту природу інтегрованої відновлювальної енергї̈, наприклад, вітрогенераторів та фотоелектричних генераторів, які залежать від погодних умов та зміни клімату, це впливає на стабільність мікромережі, враховуючи коливання частоти та відхилення потужннсті, які можнн поліпиити за допомогою вибраного контролера. Контролер дробового порядку має п'ять параметрів порівняно 3 класичним РID-контролером, щңо робить його більш гнучким та надійним щцодо збурень мікромережі. Параметри РІD-контролера дробового порядку оптимізовані за допомогою нової методики оптимізації під назвою "зграя криля», яка обрана як підходящий метод оптимізації порівняно з іншими методами, такими як оптимізація методом рою частинок. Результати показують кращі показники роботи цісї системи за допомогою алгоритму «зграя криля", заснованого на РID-контролері дробового порядку, виключаючи коливання частоти та відхилення потужності порівняно 3 класичним РID-контролером. Отримані результати порівнюються з РID-контролером дробового порядку, оптимізованим за допомогою оптимізацї методом рою частинок. Запропонована система моделюсться в номінальному режимі роботи та використовує відключення накопичувальних пристроїв, таких як акумулятор та маховик, щоб перевірити надійність запропонованих методів та порівняти отримані результати. Бібл. 18, рис. 8.

Ключові слова: мікромережа, регулювання частоти, FOPID-контролер, метод «зграя криля», оптимізація методом рою частинок.

Introduction. The increase in energy demand, the technologies evolution and the depletion of fossil fuel lead towards the use of renewable energy generation. As energy production moving to the renewable, photovoltaic system and wind generators appear to be the fastest technologies in the power system. This attention for saving climate against greenhouse gas emission has made researchers study various non-polling sources such as solar and wind system which are considered the most used renewable energy generation [1]. All this has given rise to the integration of renewable energy resources like wind and solar with distributed energy resources and energy storage systems such as batteries, flywheels and ultra-capacitor [2]. The intermittent nature of solar radiations, and wind speed, is resulted in the dependence of these resources on the weather conditions at any time [3]. This can result in an unbalance between electrical load and generation and sometimes result in unstable operation of the microgrid. This unbalance improved by the use of storage energy devices and conventional sources in hybrid power system based renewable energy generation. These storage systems store the surplus power from the renewable energy sources overly the demanded power in order to rid it later when the generated power is insufficient to feed the load demand. Many kinds of research investigate to study of power generation system based renewable generation systems such as wind and thermal solar in a hybrid system with a storage system and diesel generator [4, 5]. The importance of storage energy systems such as batteries, aqua electrolyser, fuel cell, ultracapacitor, and super magnetic energy storage (SMES) lead to analysis and control of various hybrid system configurations as in [6-9]. However, the use of conventional sources such as diesel generator and

(C) M. Regad, M. Helaimi, R. Taleb, H. Gabbar, A. Othman 
energy storage devices control the mismatches in frequency and power deviations and assure the operation of the hybrid energy system in isolated areas independently of the main grid. These fluctuations in microgrid power and frequency must be controlled due to the intermittent and stochastic nature of renewable energy resources.

The control of frequency and power fluctuation is a big challenge faced by the use of the hybrid system over the wide domain. Even though many studies interest the control of hybrid energy systems using deferent strategies control among this PID controller, Fuzzy logic controller, and fractional PID controller etc. These studies show the high robustness of these proposed control schemes and enhance the performance of the hybrid energy system [6]. The fractional-order controller is widely considered the best controller for frequency and power fluctuations in the hybrid power system, in some cases, the FOPID and PID classic are integrated into hybridizing with other controllers like fuzzy logic which can give better performance of the system but with complexity in design and implementation.

The fractional controller is defined as the generality of the classical PID controller with the addition of two parameters in order to give more flexibility to the robustness of this controller. It has found suitable applications in microgrid frequency and hybrid energy systems [5].

In this paper, the fractional PID controller is used to control the frequency and power deviations for its robustness shown by the previous studies as in [8]. Many evolutionary optimization methods have been employed for tuning the controller parameters and given more improvement to the control strategies. Among these methods are widely used the Evolutionary Algorithm (EA), Genetic Algorithm (GA), and Particle Swarm Optimization (PSO) and so one [3, 7, 17]. Recently a new optimization technique called Krill Herd $(\mathrm{KH})$ algorithm has been invented based on the behaviour of Krill in the research of food [13]. This technique is used to optimize the PID controller parameters in [16]. In our study, the Krill Herd is employed to optimize the two proposed controller and compared with PSO. The rest of this paper is summarized as fellow: the microgrid model is presented in section 2; the controller scheme is presented in section 3 ; in section 4 optimization technique and objective function are reported; in section 5 the results are analyzed and compared. This paper is ended by a conclusion in section 6 followed by a reference.

Microgrid concept. The proposed microgrid consists of two renewable energy resources like wind turbine generators and photovoltaic systems with diesel engine generator and fuel cell system as secondary sources along with energy storage systems like batteries and flywheel for store the surplus of generated power in order to release them later [1]. For small-signal analysis, the wind turbine generator (WTG), photovoltaic (PV), fuel cell (FC), and diesel energy generator (DEG) are modeled by a transfer function in the first order as showed in Fig. 1 [5].
Modeling of different generation components. For small-signal analysis, the dynamics of the WTG, PV, FC, and DEG can be modeled by the first-order transfer function. The model has been considered for analysis and demonstration of frequency behaviour in different cases [1]

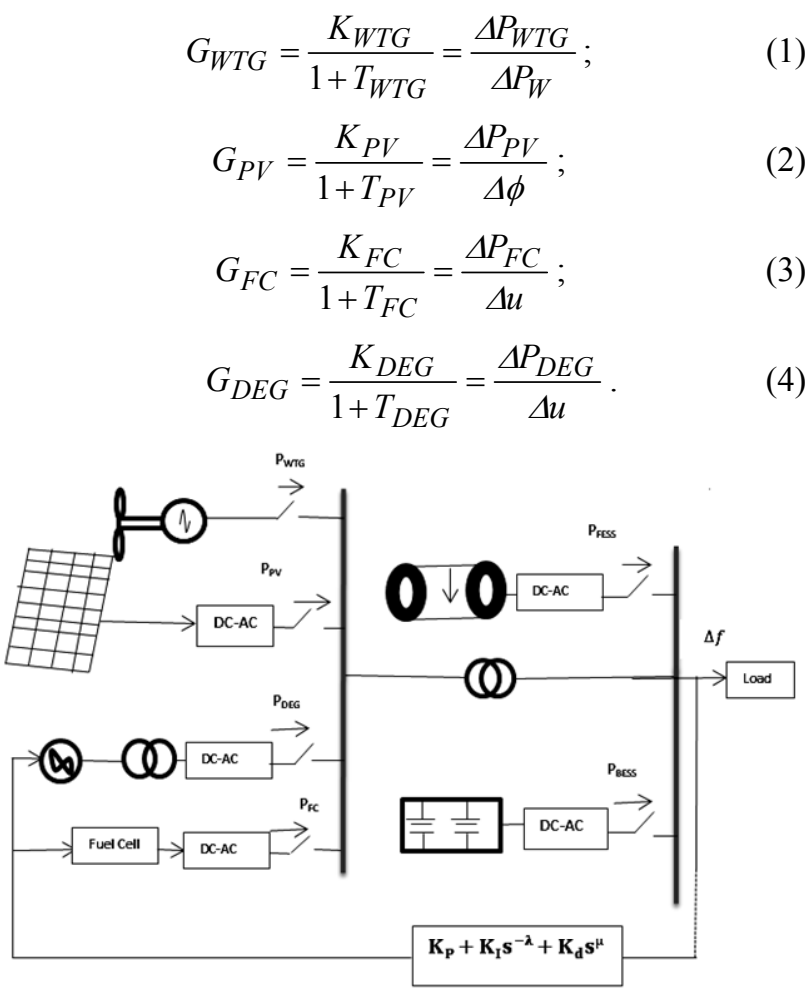

Fig. 1. Schematic of the hybrid system with energy storage and regeneration compounds

Models of energy storage systems. Energy storage plays an important role in the hybrid energy system in order to absorb the surplus power from renewable energy sources and release to loads if a deficit amount of power. The battery energy storage system (BESS) is slower to charge and discharge; its time constant is limited. On the other hand flywheel energy storage system (FESS) stores mechanical energy in a rotating flywheel rotor and retrieves it later as an electrical output. It can supply high power in a short time. The transfer functions of the BESS and FESS can be presented by a first-order transfer function as given next $[1,5,8]$

$$
\begin{aligned}
& G_{B E S S}=\frac{K_{\text {BESS }}}{1+T_{B E S S}} ; \\
& G_{F E S S}=\frac{K_{F E S S}}{1+T_{F E S S}},
\end{aligned}
$$

where $K_{B E S S}$ and $K_{F E S S}$ are the gain constants, $T_{B E S S}$ and $T_{F E S S}$ are time constants, of BESS and FESS respectively.

Power generation characteristics with loads power. Small stochastic power fluctuation and large deterministic drift reckoning for solar power generation, wind power generation and load demand power can be modeled as [5]

$$
P=\left(\frac{\phi \cdot \eta \cdot \sqrt{\beta} \cdot(1-G(s))+\beta}{\beta}\right) \cdot \Gamma=\Gamma \cdot X,
$$


where $\phi$ is the stochastic component of the power, $P$ represents the wind or solar and load powers, $\beta$ presents the mean value of the power, $\eta$ is a constant normalizes the generated or demand powers $(X)$ constant to correspondence per unit (p.u.) level, and $\Gamma$ is timedependent switching signal with a gain causes sudden fluctuation of the average value for stochastic power $[5,8]$. For the wind power generation the parameters of (7) are

$$
\varphi \sim U(1,1), \eta=0.8, \beta=10, G(s)=\frac{1}{10^{4}+1}
$$

and

$$
\Gamma=0.24 \cdot h(t)-0.04 \cdot h(t-140),
$$

where $h(t)$ is the Heaviside step function.

For the solar power generation the parameters of (7) are

$$
\varphi \sim U(1,1), \eta=0.9, \beta=10, G(s)=\frac{1}{10^{4}+1}
$$

and

$$
\Gamma=0.05 \cdot h(t)-0.02 \cdot h(t-180),
$$

For the demand load the parameters of (7) are

$$
\varphi \sim U(1,1), \eta=0.8, \beta=10, G(s)=\frac{1}{300 s+1}+\frac{1}{1800 s+1}
$$

and

$$
\begin{aligned}
& \Gamma=\frac{1}{X}\left[\begin{array}{l}
0.9 \cdot h(t)+0.03 \cdot h(t-110)+0.03 \cdot h(t-130)+ \\
+0.03 \cdot h(t-150)-0.15 \cdot h(t-170)+ \\
+0.1 \cdot h(t-190)
\end{array}\right]+ \\
& +0.02 h(t) .
\end{aligned}
$$

Fractional order PID controller. PID controller is a specific control loop feedback technic generally used in the industrial control system [6]. The PID controller consists to correct the error between a measured process variable and the desired set point. The $\mathrm{PI}^{\lambda} \mathrm{D}^{\mu}$ controller is defined as a generalization of classical PID controller, Since these fractional controllers have two parameters more than the conventional PID controller: the order of fractional integration $\lambda$ and that of fractional derivative $\mu$, two more specifications can be met, thus can enhance the performance of the system and could lead to more robust control performances, more adequate modeling and adds more flexibility to controller design. We can control our real-world processes more accurately [7]. The FOPID controller has three parameters similar to the PID controller along with the two additional parameters namely; the integral order $\lambda$, and the differential order $\mu$. The transfer function of FOPID controller in Laplace domain is given as presented in Fig. 2 [8, 12]. At Fig. $2 y(t)$ is controller output, $k_{\mathrm{p}}$ is proportional constant gain, $k_{\mathrm{i}}$ is integration constant gain, $k_{d}$ is derivative constant gain, $\lambda$ is order of integration, $\mu$ is the order of differentiators.

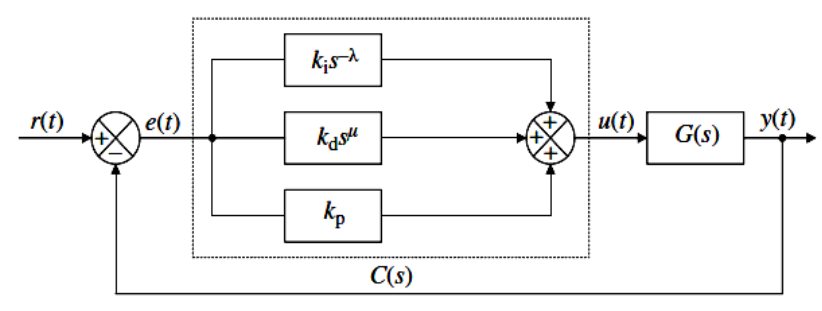

Fig. 2. Fractional order PID controller

When taking $\lambda=\mu=1$ the result is the classical PID controller (Fig. 3).

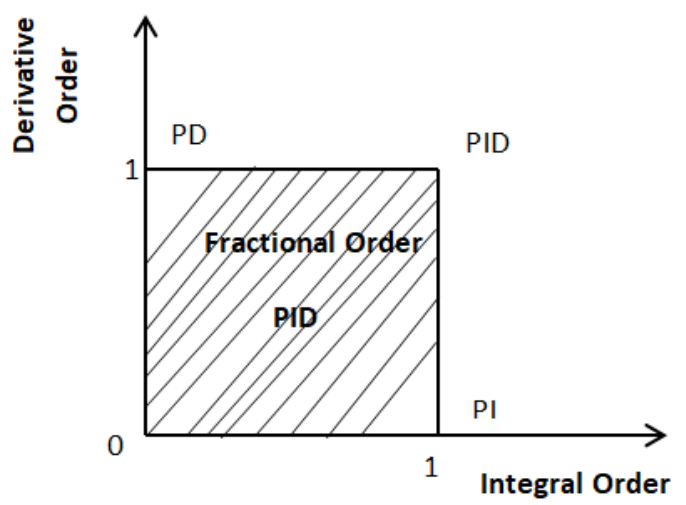

Fig. 3. Expanding from Point to Plane

Due to the presence of stochastic terms in generation and load, the optimization of the parameters controller leads to eliminate the frequency and power deviation.

We will design fractional-order PID controllers using the Krill Herd and display the advantages of the fractional-order controllers.

Objective function and optimization of FOPID controller. For the effective functioning of the hybrid system, the fractional PID controller parameters need to be determined. For this problem, the objective function in (11) is used to minimize the frequency deviation (as well as the control signal ISE (Integral of Squared Error) is used as a fitness function for the optimization of controller parameters). The fitness function has been defined as integration between the $T_{\min }$ and $T_{\max }$ simulation period, using the sum of square frequency deviation $\Delta F$ and the deviation of the control signal $(\Delta u)[5]$

$$
J=\int_{T_{\min }}^{T_{\max }}\left[w \cdot \Delta F^{2}+\left(\frac{1-w}{K_{n}}\right) \cdot \Delta u^{2}\right] d t,
$$

where $w$ represents the Integral of Square Error (ISE) of frequency deviation and the Integral of Squared Deviation of Controller Output (ISDCO).

Overview of Krill Herd Algorithm. KH is a novel optimization technique for resolving the optimization problem [13]. This technique is inspired by the simulation of the herding of Krill swarm in the response of specific biological environment processes. It is characterized by three main actions described as follows [14, 15]:

1. Movement induced by other krill;

2. Foraging action;

3. Random diffusion. 
In $\mathrm{KH}$, the Lag radian model is used in $d$-dimensional decision space as shown in [16]

$$
\frac{d X_{i}}{d t}=N_{i}+F_{i}+D_{i}
$$

where $N_{i}$ is the motion induced by other Krill; $F_{i}$ is the foraging motion, and $D_{i}$ is the physical diffusion of the $i$ th krill.

Krill Herd algorithm [16] is next:

\section{Begin}

Step 1: initialization.

Step 2: fitness evaluation.

Step 3: While the termination criteria.

Step 4: end while

Step 5: post-processing the results and visualization End

Overview of Particle Swarm Optimization. Many problems have not an exact solution that gives the results in a reasonable time. For overcoming these problems some metaheuristics methods offer an approached solution after much iteration are recently proposed. Among these methods, the PSO algorithm has a general principle to be applied in many fields of optimization problems. PSO is a stochastic optimization algorithm developed by Eberhart and Kennedy, inspired by the social behaviour and fish schooling of bird flocking. Each particle in the swarm is a different possible set of the unknown parameters of the objective function to be optimized. The swarm consists of $N$ particles moving around in a $D$-dimensional search space. Each particle is initialized with a random position and a random velocity $[17,18]$. The new velocity can be calculated by the fellow formula.

$$
\begin{gathered}
V_{i+1}=w \cdot V_{i}+C_{1} \cdot r_{1} \cdot\left(P_{\text {best }}-X_{i k}\right)+ \\
+C_{2} \cdot r_{2} \cdot\left(G_{b e s t}-X_{i}\right), \\
X_{i+1}=X_{i}+V_{i}+1,
\end{gathered}
$$

where $V_{i}$ is the component in the dimension of the particle velocity in iteration, $X_{i}$ is the component in the dimension of the particle position in iteration, $C_{1}$ and $C_{2}$ are constant weight factors, $P_{\text {best }}$ is the best position achieved so far by particle, $G_{\text {best }}$ is the best position found by the neighbours of particle, and are random factors in between 0 and 1 interval, and $w$ is inertia weight which is started from a positive initial value $\left(w_{0}\right)$ and decreases during the iterations by

$$
W_{k+1}=\beta \cdot W_{k} .
$$

The algorithms of PSO can be described as follows:

Step 1: Initialize a population of particles with random positions and velocities on $D$-dimensions in the problem space.

Step 2. Evaluation of desired optimization fitness function in $D$ variables for each particle.

Step 3. Comparison of particle's fitness evaluated with its best previous position. If the current value is better, then set the best previous position equal to the current value, and $p_{i}$ equals to the current location $x_{i}$ in $D$ dimensional space.
Step 4. Identifying the particle in the neighbourhood with the best fitness so far, and assign its index to the variable $g$.

Step 5. Change velocity and position of the particle according to Equation (13) and (14).

Step 6. Return to step 2 until a criterion is met or end of iterations.

Results and discussions. The proposed configuration of the microgrid system is executed using MATLAB/Simulink Sawford under different operating conditions in various power scales (Fig. 4). Per unit is considered as the principal unit of all power values.

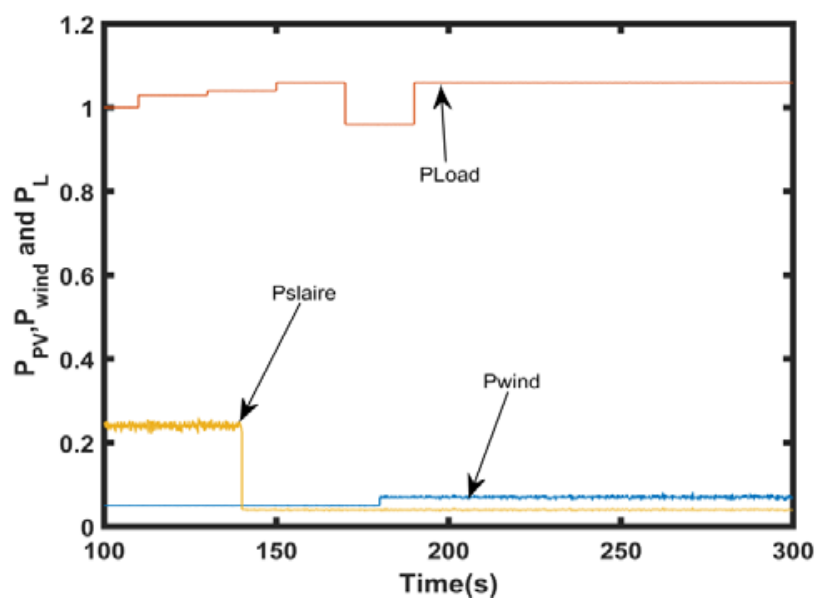

Fig. 4. Power generation from wind and solar system with demand load

Robustness of FOPID using KH and PSO under nominal conditions. In this subsection, the system is simulated under the nominal condition with the application of FOPID optimized using PSO and $\mathrm{KH}$. A comparison between the two optimization techniques is represented on Fig. 5, 6.
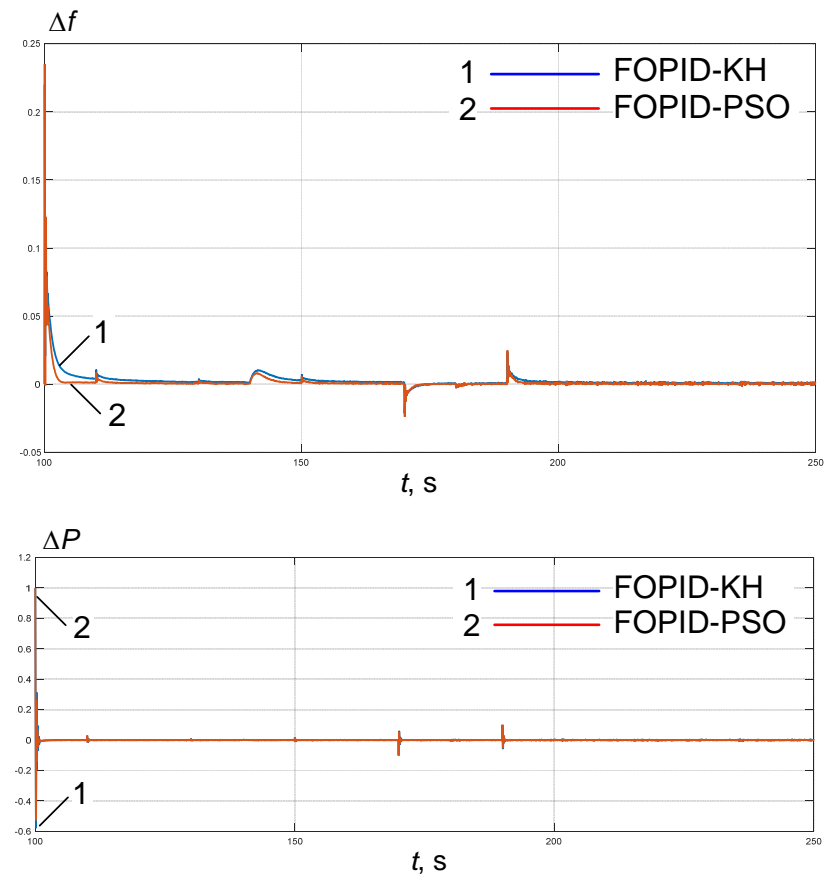

Fig. 5. Frequency and power deviation using best FOPID based $\mathrm{KH}$ and PSO 


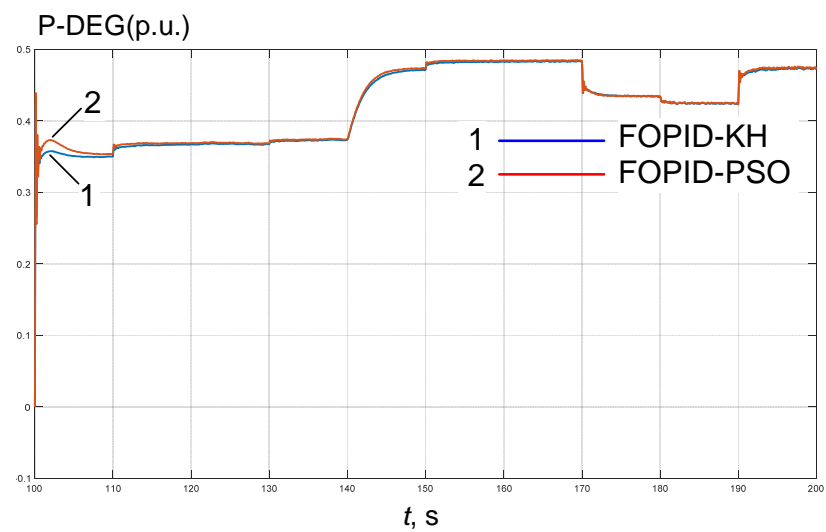

shows the frequency response of the system under FESS and BESS disconnecting.
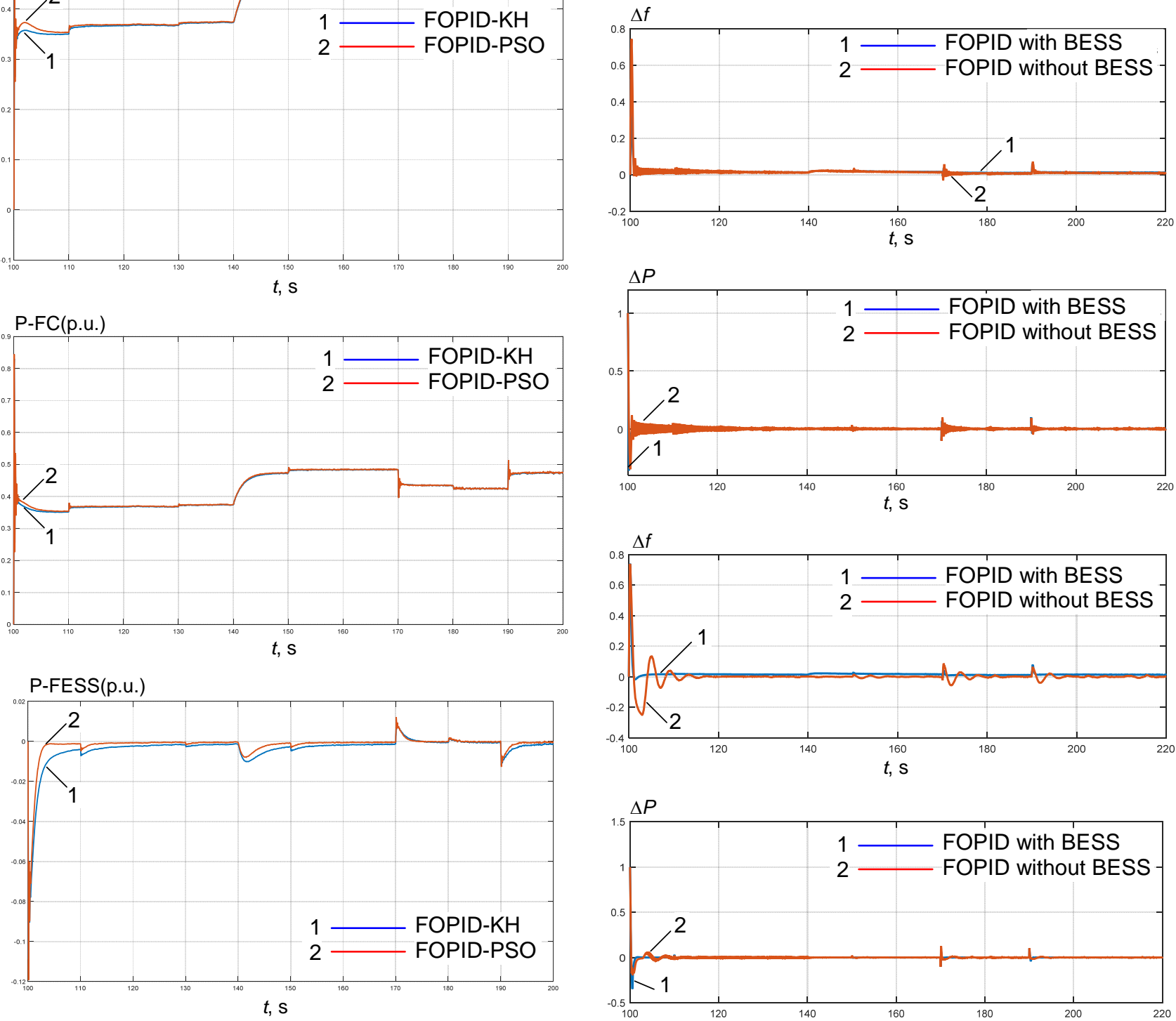

P-BESS(p.u.)

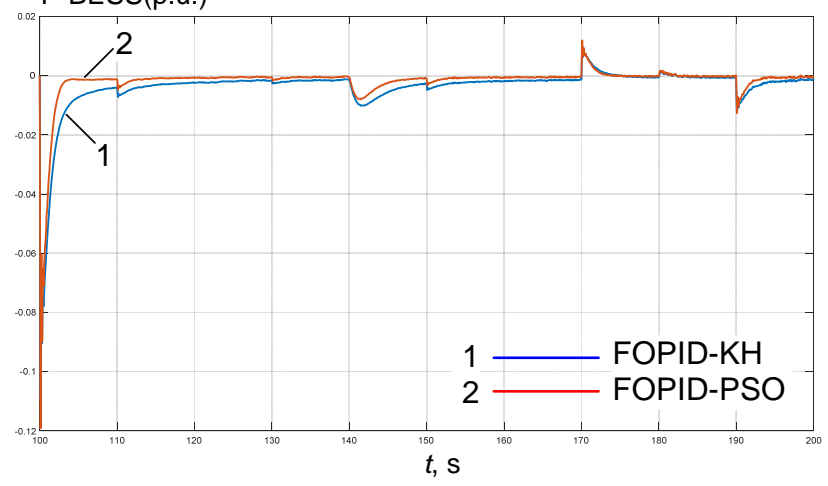

Fig. 6. The output power of different component of Microgrid using best FOPID

Robustness against Disconnecting of BESS and FESS using KH based FOPID. The system is simulated with and without FESS using the FOPID controller which optimized by KH. The obtained results are compared and shown the marked effect of the disconnecting flywheel energy storage system that required adequate control. This control necessity is achieved by applying FOPID. Fig.7
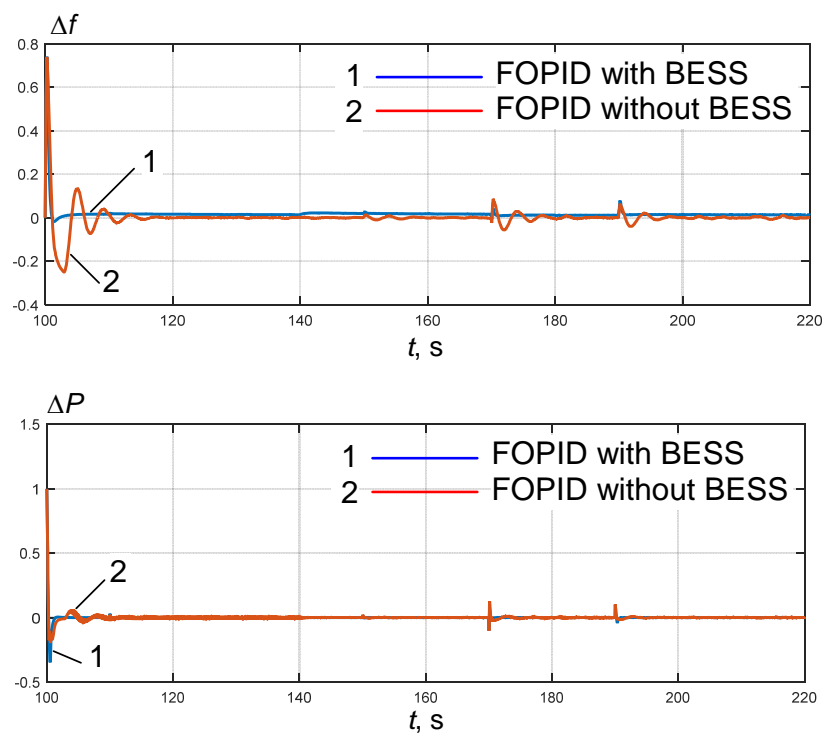

Fig. 7. Impact of BESS and FESS absence using KH with best FOPID

Comparison of PID and FOPID. The proposed system is simulated under nominal conditions using FOPID and PD controllers based on Krill Herd. A comparison is achieved between the two controllers and the results are shown in Fig. 8.

Discussions. The proposed controllers are tuned using Krill Herd and Particle Swarm Optimization in object to testing the system robustness. The system is simulated without the BESS, FESS, and DEG respectively and the effect of these components is tested using FOPID based $\mathrm{KH}$ and PSO. Then the obtained results are compared. The previous figures show different results. The result of the comparison of FOPID and PID is shown using KH running for 100 iterations. Though, the optimization method is a convenient technique that can be applied in this type of optimization issue.

Fig. 8 displays the obtained results of frequency and power response for FOPID and PID parameters. From these figures it can be easily observed that frequency 

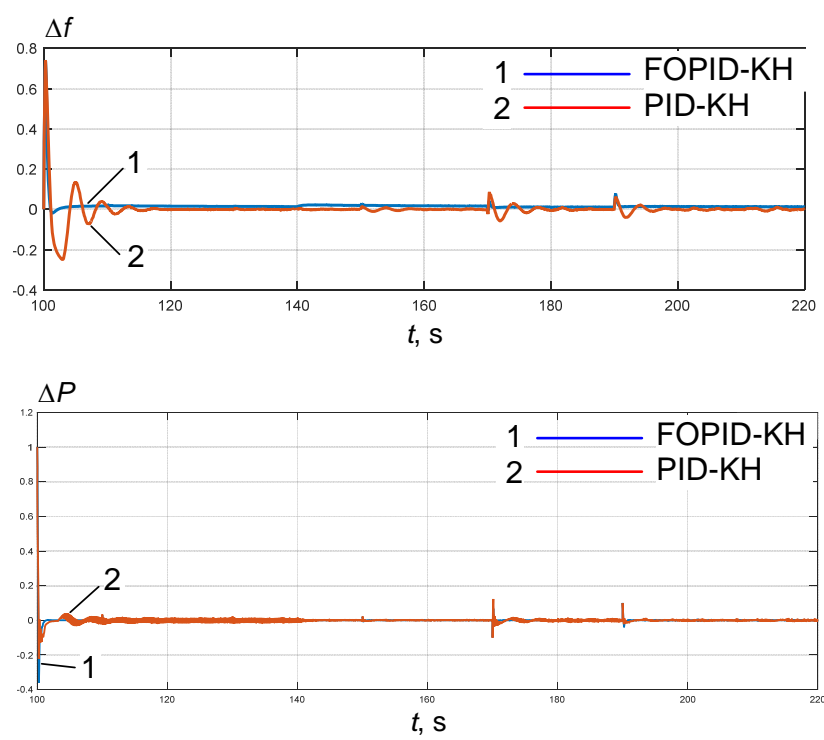

Fig. 8. Frequency and power variations using $\mathrm{KH}$ based the best FOPID and PID

deviation reaches zero in the face of disturbances in loads and generation units. These sudden changes in power generations and loads demand to have an important effect on frequency and power variations. The main objective of this letter was to analyze and improve the frequency control. A remarkable better performance of the system can be reached using FOPID controllers based on Krill Herd in comparison with FOPID based PSO. The obtained results present that KH-FOPID performed better than KH-PID due to its low-frequency variation and rapid transient variation. It is also shown that the frequency and power fluctuations in microgrid using FOPID-KH are small than with FOPID- PSO.

\section{Conclusions.}

This paper addresses the application of a fractionalorder PID controller for microgrid frequency control using Krill Herd to eliminate the influence of the mismatches between the generation and loads which causes high fluctuation of frequency and power in microgrid system based on renewable energy generation. Various Microgrid components are modeled by a transfer function in the first order to simplify the simulation process. The simulation results showed that the Krill Herd based FOPID controller scheme is favourable to send away the frequency and power deviations under perturbation operation conditions in comparison with PSO based FOPID controller because the frequency deviation is small with FOPID-KH (around 0.218) than for FOPID-PSO (around 0.235) and the power deviation varies from 1 p.u to -0.5 p.u with FOPID-KH and from 1 p.u to -0.6 p.u with FOPID-PSO which signify the best performances with FOPID-KH. Furthermore, the proposed controller is suitable to control the perturbation string along with renewable energy sources intermittences and sudden variation in power load. The generated power from DEG is enhanced using the FOPID-KH than by FOPID-PSO as shown (P-DEG equal to 0.41 p.u for FOPID-KH and 0.426 p.u for FOPID-PSO). Form the presented results it can be easily observed that the Krill
Herd is considered as the best optimization technique in terms of rapid response, good robustness to tuning the controller parameters and to improve the proposed system performance. In conclusion, the selected control strategy based optimization technique gives high suitability in microgrid frequency control.

\section{REFERENCES}

1. Lee D.-J., Wang L. Small-Signal Stability Analysis of an Autonomous Hybrid Renewable Energy Power Generation/Energy Storage System Part I: Time-Domain Simulations. IEEE Transactions on Energy Conversion, 2008, vol. 23, no. 1, pp. 311-320. doi: 10.1109/tec.2007.914309.

2. De Souza Ribeiro L.A., Saavedra O.R., De Lima S.L., De Matos J. Isolated Micro-Grids With Renewable Hybrid Generation: The Case of Lençóis Island. IEEE Transactions on Sustainable Energy, 2011, vol. 2, no. 1, pp. 1-11. doi: 10.1109/tste.2010.2073723.

3. Kouba N.EL.Y., Menaa M., Hasni M., Boussahoua B., Boudour M. Automatic generation control in interconnected power System with integration of wind power generation using PID based on particle swarm optimization. International Conference on Renewable Energies and Power Quality (ICREPQ'14), Cordoba (Spain), 8-10 April 2014.

4. Senjyu T., Nakaji T., Uezato K., Funabashi T. A hybrid power system using alternative energy facilities in isolated island. IEEE Transactions on Energy Conversion, 2005, vol. 20, no. 2, pp. 406-414. doi: 10.1109/tec.2004.837275.

5. Pan I., Das S. Kriging based surrogate modeling for fractional order control of microgrids. IEEE Transactions on Smart Grid, 2015, vol. 6, no. 1, pp. 36-44. doi: 10.1109/tsg.2014.2336771.

6. Pan I., Das S. Fractional order fuzzy control of hybrid power system with renewable generation using chaotic PSO. ISA Transactions, 2016, vol. 62, pp. 19-29. doi: 10.1016/j.isatra.2015.03.003.

7. Das D.Ch., Roy A.K., Sinha N. Genetic algorithm based PI controller for frequency control of an autonomous hybrid generation system. Proceedings of the International MultiConference of Engineers and Computer Scientists (IMECS 2011), 2011, vol. 2, 16-18 March, 2011, Hong Kong.

8. Regad M., Helaimi M., Taleb R., Gabbar H.A., Othman A.M.Fractional Order PID Control of Hybrid Power System with Renewable Generation Using Genetic Algorithm. 2019 IEEE 7th International Conference on Smart Energy Grid Engineering (SEGE), Aug. 2019, Oshawa, ON, Canada, pp. 139-144. doi: 10.1109/sege.2019.8859970.

9. Pandey S.K., Mohanty S.R., Kishor N., Catalão J.P.S. Frequency regulation in hybrid power systems using particle swarm optimization and linear matrix inequalities based robust controller design. International Journal of Electrical Power \& Energy Systems, 2014, vol. 63, pp. 887-900. doi: 10.1016/j.ijepes.2014.06.062.

10. Regad M., Helaimi M., Taleb R., Toubal Maamar A.E. Optimum Synthesis of the PID Controller Parameters for Frequency Control in Microgrid Based Renewable Generations. Smart Energy Empowerment in Smart and Resilient Cities, 2019, pp. 546-556. doi: 10.1007/978-3-030-37207-1_58.

11. Wang L., Lee D.-J., Lee W.-J., Chen Z. Analysis of a novel autonomous marine hybrid power generation/energy storage system with a high-voltage direct current link. Journal of Power Sources, 2008, vol. 185, no. 2, pp. 1284-1292. doi: 10.1016/j.jpowsour.2008.08.037.

12. Biswas A., Das S., Abraham A., Dasgupta S. Design of fractional-order PI $\lambda \mathrm{D} \mu$ controllers with an improved differential 
evolution. Engineering Applications of Artificial Intelligence, 2009, vol. 22, no. 2, pp. 343-350. doi: 10.1016/j.engappai.2008.06.003.

13. Gandomi A.H., Alavi A.H. Krill herd: A new bio-inspired optimization algorithm. Communications in Nonlinear Science and Numerical Simulation, 2012, vol. 17, no. 12, pp. 4831-4845. doi: 10.1016/j.cnsns.2012.05.010.

14. Gandomi A.H., Talatahari S., Tadbiri F., Alavi A.H. Krill herd algorithm for optimum design of truss structures. International Journal of Bio-Inspired Computation, 2013, vol. 5, no. 5, pp. 281-288. doi: 10.1504/ijbic.2013.057191.

15. Yaghoobi S., Mojallali H. Tuning of a PID controller using improved chaotic Krill Herd algorithm. Optik, 2016, vol. 127, no. 11, pp. 4803-4807. doi: 10.1016/j.jjleo.2016.01.055.

16. Alikhani A., Suratgar A.A., Nouri K., Nouredanesh M., Salimi S. Optimal PID tuning based on Krill Herd optimization algorithm. The 3rd International Conference on Control, Instrumentation, and Automation, Dec. 2013. doi: 10.1109/icciautom.2013.6912801.

17. Regad M., Helaimi M., Taleb R., Othman A.M., Gabbar H.A. Frequency Control in Microgrid Power System with Renewable Power Generation Using PID Controller Based on Particle Swarm Optimization. Smart Energy Empowerment in Smart and Resilient Cities, 2019, pp. 3-13. doi: 10.1007/978-3030-37207-1 1.

18. Iruthayarajan M.W., Baskar S. Evolutionary algorithms based design of multivariable PID controller. Expert Systems with Applications, 2009, vol. 36, no. 5, pp. 9159-9167. doi: 10.1016/j.eswa.2008.12.033.

Received 22.01.2020
Mohamed Regad ${ }^{1}$, PhD student,

M'hamed Helaimi ${ }^{1}$, Doctor of Electrical Engineering, Rachid Taleb ${ }^{1}$, Professor,

Hossam Gabbar ${ }^{2}$, Professor,

Ahmed Othman ${ }^{3}$, Doctor of Electrical Engineering,

${ }^{1}$ Electrical Engineering Department,

Laboratoire Génie Electrique et Energies Renouvelables

(LGEER),

Hassiba Benbouali University, Chlef, Algeria,

e-mail: mohd.regad@gmail.com,

m.helaimi@univ-chlef.dz,rac.taleb@gmail.com

${ }^{2}$ Faculty of Energy Systems and Nuclear Science,

University of Ontario Institute of Technology (UOIT),

Oshawa, Canada,

e-mail: hossam.Gaber@uoit.ca

${ }^{3}$ Electrical Power and Machine Department,

Faculty of Engineering,

Zagazig University, Zagazig, Egypt,

e-mail: ahmed_othman80@yahoo.com

\section{How to cite this article:}

Regad M., Helaimi M., Taleb R., Gabbar H., Othman A. Optimal frequency control in microgrid system using fractional order PID controller using Krill Herd algorithm. Electrical engineering \& electromechanics, 2020, no.2, pp. 68-74. doi: 10.20998/2074-272X.2020.2.11. 